\title{
Transcendence, Consciousness and Order: Towards a Philosophical Spirituality of Organization in the Footsteps of Plato and Eric Voegelin
}

\author{
Tuomo Peltonen ${ }^{1}$ (iD \\ Published online: 7 January 2019 \\ (C) The Author(s) 2019
}

\begin{abstract}
There is an evident lack of rigorous frameworks for making sense of the role and status of spirituality and religion in organizations and organizing, in particular from the perspective of spiritual philosophies of the social. This paper suggests that the philosophy of Plato and his modern follower, political theorist Eric Voegelin could offer a viable perspective for understanding organizational spirituality in its metaphysical, political and ethical contexts. Essential for such a philosophical reflection is the postulation of the transcendental realm as the ultimate reality that provides the fullest templates for order, knowledge and ethicality. It is argued, in the footsteps of Voegelin, that modern organizations and modern organization theory should seek to re-awaken the lost experiences of the divine Beyond by re-animating religious symbols and myths of transcendence as devices for a spiritually opened consciousness.
\end{abstract}

Keywords Spirituality $\cdot$ Religion $\cdot$ Consciousness $\cdot$ Voegelin

\section{Spirituality and Organization and the Space for Philosophical Spirituality}

Reflection on the role of spirituality in organizations and organizing has been growing exponentially during the 2000's (Poole 2008; Pandey and Gupta 2008; Benefiel et al. 2014). With a specific niche within the broad field of management and organization studies, inquiry into spirituality and religion has come to be recognized in the academic debates and structures as a topic in its own right, as demonstrated for example by the interest group within Academy of Management devoted to the study and practice of management, spirituality and religion.

Yet at the same time, what exactly constitutes the object of interest for organizational spirituality scholarship and how it should be theorized remains something of an enigma (Case et al. 2012; Benefiel 2003; McKee et al. 2008; Giacalone and Jurkiewicz 2003a, b). Broadly speaking, it is possible to sketch three major approaches to the nature of spirituality (and religion)

Tuomo Peltonen

Tuomo.Peltonen@abo.fi

1 Faculty of Business, Åbo Akademi University, Fänriksgatan 3, 20500 Åbo, Finland 
in organizational life (Peltonen 2017). Firstly, those following an empiricist stance focus on the spirituality and religion as a measurable variable affecting and being affected by various organizational phenomena (Mitroff and Denton 1999; Karakas 2010; Fry 2003; Giacalone and Jurkiewicz 2003b). Spirituality is here understood as an exogenous variable or mechanism in the causal dynamics of organizational processes. Secondly, spirituality and religion could be viewed as an intrinsic property of the socio-psychological landscape of organizational life. Here, the focus moves to the meaning of spirituality as experienced and enacted in the constitution of organizational and personal reality. In psychology, the inquiry into spirituality would follow the pragmatist or phenomenological program initiated by James (1902), for whom religion "...[was] the feelings, acts, and experiences of individual men in their solitude, so far as they apprehend themselves to stand in relation to whatever they may consider the divine" (James 1902, 31-32). In sociology, in turn, the role of the religious would be interpreted in the footsteps of Durkheim (1912), who understood religiousness as eminently social phenomena that reflected and reproduced the cosmological structure of collective myths and rituals, giving raise to sociocultural orders. Both Jamesian psychology and Durkheimian structuralism approaches spirituality and religiousness as an endogenous part of the socio-psychological reality, paving way for an interpretative study of religious experiences and communities.

However, there is a third way of interrogating spirituality and religion that departs from the broadly naturalistic (Plantinga 2011) outlook of the empiricist and cultural-social interpretations (Hume 1957). Here, spirituality is not seen as an exogenous variable neither an endogenous modality, but a reference to the transcendental ground of being in its dialogue with the emanated human world (Hughes 2003). Religious or spiritual beliefs and experiences have an absent referent or hypostasis. Such a position resonates broadly with a traditional theistic understanding of the Abrahamic faiths, but is here discussed primarily as a distinct philosophical, non-denominational interpretation of religion (Cooper 2006). ${ }^{1}$ The transcendental variant could be called, in absence of a better term, a philosophical spirituality: a commitment to a spiritual metaphysics that assigns to a religious or transcendental reality a priority over the material, empirical and immanent realm of social, political and cultural dynamics. $^{2}$ At the center of this approach is the (divine) other-worldly realm, and its role in the valorization and ordering of the human and social life. Spiritual philosophizing finds its strongest advocates in the tradition initiated by Plato (1993; Klosko 2006), and carried forward by his followers within the philosophical school of Neoplatonism (Remes 2008; O'Meara 2003), and, further, by the many thinkers, theologians and theorists who have conveyed Plato's views into modern discussions (e.g. Murdoch 1994; Voegelin 1952).

The purpose of this article is to advance the understanding of organizational spirituality as a Platonist metaphysics of the transcendental in its implications for a reformed theory of order of organizational being and action. This is accomplished in three steps: the second section of the paper discusses the relative absence of a Platonist spiritual philosophy in light of the historical development of organization theory. The third part of the article reconstructs the main spiritual elements of Plato's metaphysics of Forms, and the formation and rule of the Philosopher-King,

\footnotetext{
${ }^{1}$ Alternatives to theism include naturalistic pantheism (God is Nature/Nature is God) and panentheism (God is transcendent, but is affected by the immanent world). Most modern philosophers subscribe either to pantheism (e.g. Spinoza) or to panentheism (e.g. Hegel, Whitehead) (Cooper 2006). Within a related conceptual taxonomy, atheism argues for a denial of supernatural beings, whereas agnosticism leans on epistemological skepticism towards God (Draper 2017; Bell and Taylor 2016).

${ }^{2}$ The three-fold division into empiricist, cultural-social and transcendentalist schools follows the established classifications of different approaches to the study of religion (Rodrigues and Harding 2008; Schilderman 2014)
} 
followed by section that introduces of a modern appropriation of the Platonist tradition in the political-philosophical work of Eric Voegelin. The paper closes with a concluding discussion about the implications of a Platonist-Voegelian perspective for a philosophized study of organizational spirituality and its symbolic and narrative expressions.

\section{The Genealogy of Organization Theory and the Platonist Philosophical Tradition}

Benefiel et al. (2014) have recently noted that the field of spirituality and religion within organization studies did not emerge in the footsteps of the more established traditions in the humanist and sociological study of religion. Instead, the debate on workplace spirituality originated from fragmented discourses within business ethics, management and organizational behavior. The motivations for the rise of scholarship in organizational spirituality were also heterogeneous in the sense that while there was a stream of contributions engaging with the theoretical and empirical study of spiritual practices and beliefs (Krishnakumar and Neck 2002; Benefiel 2005; Gotsis and Kortezi 2008), the field has also been characterized by a more pragmatic interest of approaching religiousness as an instrument for organizational effectiveness (Giacalone and Jurkiewicz 2003a, b; Karakas 2010).

However, there could also be a deeper explanation for the relative gap between the academic discussions in organizational spirituality and those found in philosophy, psychology and sociology of religion. This concerns the way in which organization and management theory was originally conceived of in relation to the broader development and history of theory within human sciences. Organization theory came into being as a sub-field of social sciences in the 1930's (Scott 2013). This was the time when Elton Mayo (1933), Fritz Roethlisberger (Rothlisberger and Dickson 1939), Chester Barnard (1938) and Robert Merton (1940) were crafting an early theory of organizations within the broader intellectual currents of the Harvard University. It was also the period when the new disciplines of sociology, psychology and anthropology were separating from the more general scholarly fields and claiming independence. In particular, the development of Harvard organization theory coincided with the rise of the American academic sociology and the establishment of early functionalist theory in the figure of Talcott Parsons, another eminent Harvard scholar (Heyl 1968; Keller 1984).

The origin of self-conscious organization theory under the influence of functionalist social theory meant also that there were less opportunities for considering the more perennial questions inherited from classical philosophy and political theory. Sociology was built on the work of Durkheim, Weber, Marx and Simmel, all working in the shadow of modern continental philosophy of Kant, Hegel and Nietzsche. Parsons (1937) developed his own synthesis of idealist and utilitarian social theory (Mayhew 1984), paving way for a social science that was to have an enduring relation to economic modernity.

Organization and management theory thus initially took the shape of a systems theory focusing on the structuring of social relations in economic and societal contexts (Peltonen 2016). The input from the Carnegie school of decision-making paradigm (Simon 1947; March and Simon 1958) was followed by a period of positivist studies on organizational structures and their contingencies (Donaldson 2001). More recently, the mainstream has turned to institutional theory, which was originally inspired by Michels' (1915) analysis of oligarchy, adapted to the mid-range functionalist theories by Selznick (1949), and modernized by Scott, Meyer, Powell, DiMaggio and others (Scott 2013). New openings were initiated following the 
cultural and postmodern turn in social sciences, introducing phenomenological sociology and post-structuralism into organization studies, along with Critical Theory approaches (Burrell and Morgan 1979; Clegg et al. 2006). Yet despite of the amalgamations in the intellectual style of organizational thinking, the modernist systems of sociology have remained the uncontested base or "origin" from which organizational studies claims its identity in the broad domain of social sciences (Peltonen et al. 2018). ${ }^{3}$

This start that emphasized nascent sociological debates of the pre-WWII American academia can be seen as hindering a re-examination of organization theory as to its potential genealogies that would go deeper into the classical traditions in philosophical thought. While sociology is somewhat limited by its profile as the discourse on modernity and its consequences, the discussions in political theory (cf. Kaufman 1964) typically take a more open attitude towards classical articulations of metaphysical worldviews. The field of political philosophy (Arnhart 2002) in particular has maintained a lively contact to the views of Greek philosophy inherent in the works of Plato and Aristotle, and Augustine, Aquinas and Neoplatonism. For example Leo Strauss (1959), one of the leading political philosophers of the twentieth century, insisted that the interest of ancient philosophy on other-worldly sources of order and knowledge is still valid as social sciences try to rediscover their mission and relevance in the circumstances of high modernity. For Strauss, the classical texts of Plato and Jewish philosopher Maimonides were to be read not as representations of thought but as performances of esoteric wisdom that animated the transcendental mysteries behind human intelligibility. In a similar vein, Eric Voegelin (1952) suggested a renewed interest in the spiritual effect of the ancient philosophical treatises that he believed could be used to revitalize our de-spiritualized age of technocratic reason and anthropocentrism.

It is this possibility of a fundamentally spiritual or transcendental philosophy of social organization offered by scholars like Voegelin, following in the footsteps of classical philosophy, that seems to be missing from the attempts to coherently theorize workplace spirituality. This type of re-appropriation of the role of spiritual otherworldliness would not only comment on and empirically observe religious beliefs and practices in organizational settings from an immanentist, naturalistic perspective (cf. Ferrara 2015), it would also build a theory of organizing and managing based on the acceptance of the transcendent or the divine as the ultimate reality. That is, the spiritual should be (re)discovered in theory. The vision of Plato and the later Platonists might offer one of the most philosophically promising routes in this direction (O'Meara 2005; Louth 2007) and it is to these traditions that we turn next.

\section{Plato and Platonists on the Other-Worldly Sources of Order}

Plato's philosophy and Socratic dialogues are the beginning of a long tradition in the Western world. Later philosophy could be rightfully seen as a series of footnotes to Plato, as Whitehead (1929) famously suggested. But while Plato and Platonism have a place in the history of philosophical and political thought as a variant of idealist striving towards good life and ethical maxims, the spiritual character of Plato's (and his followers) work has not traditionally been

\footnotetext{
${ }^{3}$ Although the genealogy of organization theory has been re-examined (e.g., Burrell 1997), the canonical historical narratives of the field (Scott 2013; Burrell and Morgan 1979; Hatch and Cunliffe 2006; Morgan et al. 1983) locate the emergence of organization theory into the developments within modern social and behavioral science in the 1930's and 40's (cf. Starbuck 2003; Reed 2006). Organization theory is seen as a consequence and comment on modernity, illustrated in the rise of formal bureaucracies and industrial systems of production.
} 
registered as wholeheartedly in the domain of social and political studies. Yet as Louth (2007) notes, the mystical and religious element in Plato's philosophy is not simply a sideshow in his work, but something that penetrates and informs his whole understanding of reality, knowledge and truth. The well-known themes from his philosophy such as the simile of the Cave (Morgan et al. 1983), call for the philosopher-kings (O'Meara 2003) and the tripartite conception of the human psyche (Bauman 2018), all rest on the assumption that truth to be found in the divine realm of eternal and immaterial forms and ideas rather than in the changing and deceptive shadows of the empirical and material reality. The Forms represent in the figures of Truth, Beauty and Justice that which is fully perfect, self-sufficient and unified. The material and natural objects, and worldly phenomena are always crude replicas of the paradigmatic perfection of the Forms, including also the human nature.

At the same time, humankind has a special place between the divine Forms and the lower material and natural creations. Humans are both divine and worldly beings. Plato (1993) argued that the human soul is immortal and flows from the eternity of transcendental Forms. It is confronted with the desiring and passionate parts of the psyche in the psycho-physical constitution of the human individual. For Plato, human mind or soul is the gateway back to a union or participation with the divine realm. This can be attained primarily through contemplation, or a practice Greeks called theoria - an ascetic and spiritual practice that polishes the soul to see and take part in the extra-sensual Forms and their goodness (Nightingale 2004). Contemplative theoria requires that the soul turns to its natural divine source and shuts down the sensory machinery with its superficial understanding of knowledge and wisdom. The pathway to the fullness and perfection of the Forms calls for inner and outer meditative discipline, including purification of moral distortions that impede the opening of the soul to the Good.

Indeed, in order to approach or return to the real source of being, human subjects must strive to become perfect in the image of the divine Forms with which they are seeking to take part. Plato, and more clearly his later followers, the Neoplatonists (Remes 2008), subscribed to a view whereby the enlightenment of the human takes place through divinization or theosis, i.e., becoming a divine-like person (O'Meara 2005). The epistemological aspects of this quest in Plato's work are illustrated in the metaphor of the Cave, whereas the implications for politics and governance are articulated in the discussion about the philosopher-king. The ascent from the Cave is the contemplative journey of theoria away from the limitations of our sense data and social opinions, and higher towards the actual source of wisdom and order, represented by Sun in the Plato's story. The rise from the Cave is a holistic transformation of being, in which the human subject undergoes a rearranging of the priorities organizing his or her agency (Nightingale 2004).

For Plato (1993), philosophy is the practice of theoria in par excellence. The philosopher's task is to contemplate and follow a virtuous life path in the pursuit of divinization. Philosophy is love of wisdom, where the intellectual aspects of theoretical-metaphysical exercises meet with a holistic or even erotic union with the Forms (cf. Hadot 1995). This quest for otherworldly being puts a philosopher on a collision course with the everyday concerns of social life. With a dedication to the eternal realm that is beyond the conventional cognitive and material contexts of earthly immediacy, the philosopher becomes a metaphysical stranger to the world of action (Remes 2008). At the same time, a philosopher who manages to climb out of the Cave of sense knowledge and the disorder of daily hurly-burly, has elevated himself or herself into a higher level of wisdom and perfection. The philosopher has attained a state of spiritually rational vision and can guide his life past the perils of destructive desires and passions (Nussbaum 1998). 
And yet to establish a good society, the human community according to Plato (1993) needs to call the philosopher back from his or her divine retreat, to assume leadership of immanent practical affairs. As a philosopher-king (or queen), the divinized person must take the helm in the government of social affairs and organizations so that political life can develop towards order, justice and harmony (Klosko 2006).

The jump from the individual psyche to the constitution of community or organization is justified by the idea of the correspondence between the individual soul and the political structure of the social organization. Social community (the polis of the ancient Greece) is seen as a macroanthropos of the individual subject (Voegelin 1952), where higher and lower forces are competing for mastery. For a community to be governed wisely, it needs leaders who are morally and spiritually educated by the union with or participation in the Forms (Louth 2007). The claim is that only philosophers can deliver order and harmony to community, whereas others who are mainly directed by other forces than the wisdom of the soul take corresponding positions in the lower ranks of the social structure. These include the soldiers, who are strong in courage and national pride, and workers, who are specialized into particular tasks and occupations and governed primarily by bodily appetites and material rewards (Plato 1993).

The proposition that philosophers, who have turned away from the immanence of action and change in order to become purified in the face of reaching out to a union with the Forms, should be the rulers of practical social affairs has perplexed the modern readership. Much of the criticism of Plato's social philosophy is directed to the utopian nature of a political community where philosopher kings and queens reign (e.g. Popper 1944). Apart from the blatantly aristocratic model of society endorsed, the question is how can a person who has blinded himself or herself to the practical life of politics (Nightingale 2004), master and influence the highly socially complex challenges of state leadership (Federici 2002)? In a sense, the philosopher-king is not a reformer or champion of a movement. If put into a position of authority, he or she simply wants to return the community to its divine roots by nurturing collective soul against the disorder of passionate and desiring forces prevalent in the everyday life of polis (Louth 2007). The philosopher tries to correct the balance between different aspects of the collective psyche or culture, thus enabling social harmony. He or she is a kind teacher and saint, whose own rearrangement of the forces of the soul and body is offered for the others as the template for the collective ordering of the social spirit. The union with the divine provides the philosopher-king with a source of goodness and fullness that is generous and overflows from a particular individual to the surrounding community without emptying the person (Remes 2008).

The claim that the philosopher, the lover of divine wisdom, should be given authority to organize the surrounding community in the image of Forms, and that good community is impossible without the contemplative practice of theoria and the associated theosis or divinization (O'Meara 2003) of its citizens, has gone mostly unnoticed within the classical and modern organization theory (for an exception, see: Case et al. 2012). It is difficult to find any rigorous, extended discussion of the implications of Plato and Platonist thought within the broad scholarship on organization and management studies. Either Plato is ignored altogether as a noteworthy philosopher of organizing and managing in the reviews of the field (e.g., Tsoukas and Chia 2011; Jones and ten Bos 2007), or, alternatively, he is discussed mainly as a classical student of mythical and proto-ethical leadership (Takala 1998; Grint 1997; Williamson 2008; Klein 1988). Occasionally, the metaphor of the Cave (Morgan et al. 1983) or the notion of the philosopher-king (Chia and Morgan 1996; Cunliffe 2009; de Vries 1991) are referenced to carve an argument which is based on an erroneous or 
underdeveloped understanding of the philosophical project of Plato. The metaphysical and religious aspects of Plato (Louth 2007) and his later Neoplatonist (Remes 2008) followers' theory have been wholeheartedly omitted from the mainstream and critical reviews of the origins and genealogies of organizational thinking. Maybe because it is considered belonging to antiquity (Bauman 2018), the relevance of Plato's thought for modern questions of managing and spirituality has been unconsciously rejected. In this respect, the work of Eric Voegelin would be a welcomed correction in the dialogues between pre-modern and modern conceptions of spirituality and order.

\section{From Plato to Eric Voegelin: Reawakening the Symbols of Transcendence}

If Plato presents as a rather sketchy figure in the contemporary organization theory, the work of Eric Voegelin is even more alien to the field. ${ }^{4}$ Still, Voegelin's thinking represents the kind of "modernized" theory of spiritual encounter with the transcendent that the nascent spirituality and religion scholarship is lacking in order to be able to develop beyond conventional approaches based on naturalism and instrumentalism (Federici 2002). Therefore, the paper next introduces the profile of Voegelin and his work, and reviews the possibilities of a Voegelinian philosophical perspective for a revitalized Platonist theory of organizations and managing.

Voegelin (1952) is perhaps best known for his critique of modernity and modern social philosophy as an inherently gnostic undertaking. For him, "gnostic" means the prevalence of modern thinking to assume that the transcendental ideals can be realized in time and space. For Gnostics, Voegelin argues, the other-worldly ideas about perfect social and political order are to be realized in the immanence of our human reality and within history. Theories of modern eschatologists like Hegel or Marx rely not simply on bypassing the metaphysical dimension of existence, but on attempting to convert the mystical insights of transcendental or divine knowledge into blueprints for the constitution of good society by men.

Voegelin condemns the gnostic confidence as dangerous hubris that rejects the natural limits of human reason and transformative politics vis-à-vis the transcendental ground of being. Gnosticism starts with the discontent to the current way the world is being organized, followed by an observation that the salvation from evil is possible through the re-constitution of human nature and social structures. This is the project of human-centered transformation, applied through political action. Change is to be initiated on the basis of secret knowledge by a vanguard group of leaders (Voegelin 1967; 86-87).

The main contradiction in the gnostic re-constitution of reality is that it emulates the spiritual narrative of transcendental traditions in philosophy and religion but locates the salvation within immanent time and space. The result of Gnostic attitude, Voegelin argues, is a kind of "civic theology" that distorts the Platonist-theist message of the transcendental nature of truth and the associated moral, epistemological and political virtues into an ideology of salvation and privileged knowledge. In the Hegelian tradition, the philosopher completes the historical dialectics by engaging with secret knowledge of the Spirit (Magee 2001), while with Marx, this dynamic is played out in the material and public domain of economic production (Lukács 1971). Nietzsche, in turn, advocates a "spiritual" self-affirmation that results in the newly aestheticized human subject (Nietzsche 1994); a theme that for example Foucault later animated

\footnotetext{
$\overline{{ }^{4} \text { For exceptions, see: Harter } 2006}$ and Moreno-Riaño 2001.
} 
in his writings about ethics of the self (Foucault 1997). The spiritual dimension in these modern theories could be understood primarily as the energy or insight that is needed to push the human community past its present malaise, and to a higher state of this-worldly actuality.

Having identified the crisis of modernity as the wrong immanentization of the transcendental truth, Voegelin sets out to contemplate how to re-spiritualize the modern age. Firstly, he is not attempting simply to go to the past and apply ancient Greek philosophy to contemporary problems. Voegelin is attempting a delicate balance between universalism and historicism (Voegelin 1952; 2-3); he is aware of the pitfalls of simply reversing into the past. At the same time, however, his commitment to the political problems of the day is not intended as a direct revision of empirically identifiable institutions and structures as they are understood in the mainstream social science. His angle on the gnostic features of contemporary political organization of reality is firmly philosophical in its effort to seek new ways of installing the lost spiritual core into human existence.

The delicate project of introducing openness to the divine truth is accomplished by Voegelin by focusing on the possibilities of what could be called a spiritual consciousness. He integrates the idea of the openness and eventual union with the transcendental Beyond together with a phenomenological theory of consciousness. The basic orientation of the mind to the objects as treated in the phenomenology of Husserl (1900) is being given spiritual depth by Voegelin in a move that adds a further element into the structure and practice of human consciousness. Spiritual enlightenment occurs through the active participation of the experiencing psyche in the transcendental Beyond (Voegelin 1974; 280). The spiritual experience as understood by Voegelin is not primarily about meditative contemplation but a dynamic process in which the mind becomes aware of the absent presence of the divine omnipotence and goodness in its ongoing phenomenql construction of knowledge (Sotiropoulos 2015).

While this echoes the views of process philosophy (Whitehead 1926) where reality is an ongoing actualization of multiple potentialities, the role of the Beyond is more fundamental than in the panentheistic understandings of process philosophy and theology (Cooper 2006). Not only does human intentionality acquire new height and depth by participating in the transcendent, but it is also transformed by this active encounter. As Voegelin is keen to stress, "[t]hrough the opening of the soul the philosopher finds himself [sic] in a new relation to God; he not only discovers his own psyche as the instrument for experiencing the transcendence but at the same time discovers the divinity in its radically nonhuman transcendence" (Voegelin 1952, 67). The subject so to speak transgresses the limits of human immanent psychology and becomes aware of the spiritual ground that exceeds and precedes human intentionality.

The idea of actively participating in the transcendental hypostasis through consciousness also gives rise to the idea that when practiced systematically, it can alter the moral and epistemological configuration of individual and social subjects. Here Voegelin is clearly following in the footsteps of Plato (1993), who suggested in The Republic that philosopherkings are developed through the rigorous education of the youth. This is the domain of theoria, or the practice of engaging future leaders in spiritual and intellectual exercises that nurture a habitual sensitivity to the metaphysical truths. As Hadot (1995) has argued, ancient philosophy could be better understood as a series of educational and character forming exercises that aim to strengthen the spiritual reflexivity of the subject rather than as a set of abstract formulations and concepts. The practice of theoria in ancient Greece was a tradition of embarking on a journey of young men into religious festivals meant as a transformative process of experiencing metaphysical otherness (Nightingale 2004). It was intended to lead to a sharpening of the "eye of the soul" (Kavanagh 2004), something akin to what Voegelin understood as the 
capacity of spiritual awareness of the transcendent to gradually train the mind to de-centre its structure of consciousness towards the deeper divine truth.

But the explication of a reformed philosophy of consciousness is not sufficient to re-introduce spiritual awareness to the social and political arena of the day. As noted, Voegelin was vehemently against the idea of a simple return to the premodern times of Greek philosophy and early Christian faith (Voegelin 1952). Instead, he develops a reading of history that emphasizes its transmission from the past to the present with the help of theoretical and practical symbols. His philosophy of history underlines the interaction between universality and particularity. While the era of openness to the divine truth has been eclipsed by the rise of the immanentist ideologies, the past experiences of the transcendental Beyond can be recovered in the form of secondary symbols that direct the soul back to divinity by re-enacting the bygone experiences of mystic union. These so called reflective symbols function as openers of consciousness to the universal sensitivity of general human existence towards the spiritual realm. Thus, by re-animating the lost experiences of premodern civilizations, symbols aim to activate the soul to recognize its inherent longing for the metaphysical basis or sources of being. These include linguistic markers from the ChristianPlatonist vocabulary, but more generally any myths or narratives that arouse the spiritual imagination in the human subject (Bussanich 2007).

In sum, Voegelin takes the Platonist project of metaphysics of divine Forms to the modern age by underlining the loss of the idea of transcendent ground of being with the advancement of empirical science and immanentized philosophy. He is advocating a reawakening of the ancient experiences with the divine Beyond as a recourse to the symbols of transcendence that have lost their original meaning and spiritual content. As an integral element in the constitution of phenomenologically understood structure of consciousness, experience of the transcendent opens up human subjectivity to a higher wisdom. This experiential expansion or opening of consciousness could be basically understood as a result of spiritual-religious practices that both make metaphysical room for the transcendent by way of ascetic withdrawal from the sensory world, and engage in an active participation with the divine Forms through a philosophical way of life (Nightingale 2004; Hadot 1995).

Finally, the turn to the transcendent has a political and social dimension: the soul radiating from the participation with the divine Beyond brings order and harmony to the individual psyche by governing the lower forces within human nature. Spiritual consciousness is superior to the powers of the passionate and appetitive parts of the human person (Plato 1993). Reformed consciousness has the capacity to distinguish right order from a flawed one. This, in turn, endows the subject with the potential for describing what could approximately be the right order for society. For the most part, Voegelin's (1952) political theory follows Plato's (1993) articulation of the ideal city in The Republic: social order is a "macroanthropos" of its constituent citizens, and the stronger the spiritually rational part of the individual psyche of citizens and especially leaders, the more harmonious is the political community. Having outlined the program of Voegelin, let us now return to the implications of this philosophical understanding of spiritual experiences for the study of organizational spirituality and religion.

\section{Concluding Discussion}

There is a lack of rigorous frameworks for understanding and contemplating organizational spirituality from the perspective of philosophical spirituality (Benefiel et al. 2014). This paper has suggested that the work of Plato (1993) and Eric Voegelin (1952) could offer a viable perspective for 
understanding spirituality in its metaphysical, political and ethical contexts. Essential for such a philosophical reflection is the postulation of the transcendental, divine realm as the ultimate reality that provides the best and fullest templates for pursuing order, knowledge and ethicality (Hughes 2003). The spiritual task is to seek a contact with the transcendental ground of being and to initiate a process of personal and social transformation (Nightingale 2004).

What are the implications of Plato's and Voegelin's work for theory and practice of organizational spirituality? Firstly, as spirituality is here understood essentially as a religious experience of taking part in the transcendental Forms, the role of spirituality is considerably broader than in most of the mainstream discussions (cf. Benefiel 2003). Spirituality unavoidably deals with metaphysical questions about the ultimate reality, as well as with epistemology, ethics and politics of good life. Equipped with a vision that the transcendent is the ultimate reality, Plato and Voegelin are adamant that any account of spirituality needs by necessity to invoke the human-divine - contact and the associated quest for perfection or theosis (Hughes 1999).

Yet at the same time, Voegelin (1952), who unlike Plato and his Neoplatonist followers (Remes 2008), works within the culture of modernity (Moreno-Riaño 2001; Jardine 1995), calls for a critical deconstruction of modern ideas regarding the power of immanent human reason and societal evolution. Most of the modern philosophy has argued for a vision of humanity cleansed of its sacred, transcendental roots. There is no actual reality beyond the one observed with our senses and made intelligible with the help of our cognitive faculties. The spiritual element is typically conceptualized in modern philosophy as a pantheist world soul or creative force rather than a transcendent divinity (Cooper 2006).

Within the modern condition, religious questions related to the ultimate reality tend to become marginalized as private projects of holistic well-being and subjective meaningfulness (Heelas and Woodhead 2005). Spirituality is cut off from more comprehensive questions around naturalism, transcendentalism and the nature of spiritual truth. It is within the modern philosophical milieu of post-metaphysical understanding of reality as human-centered and materialistic, that religion is reduced to private spiritual exercises. This also helps to understand why organizational life, interpreted from the prism of the modern lens of cognitive, inter-subjective and social-material processes and mechanisms, is seen as inherently decoupled from the pursuit of religious or spiritual beliefs (Sandelands 2003; Case et al. 2012). The prevailing understanding is that organization is immanent to this-worldly human and social reality, whereas theistic religiosity and Platonist metaphysics belongs to the archaic world of mysticism and superstition; hence the talk about the separate meaning of religion and spirituality in organizational discourses (Mitroff and Denton 1999).

While the de-sacralization of social and philosophical thinking within modernity has been extensively treated in classical sociology (Weber 1920; Simmel 1905), Voegelin (1952) adds a vital normative element to the evaluation of religious and transcendental beliefs in contemporary life. His claim is that there remains always a longing or craving for the lost union with the divine Beyond, simply because, for him, the transcendental realm of Forms is fundamentally real and works all the time in the background of human imagination and existence (Federici 2002). Like the alienated prisoners in Plato's (1993) Cave wishing to break away from the narrowness of the immanent reality, the modern man and woman is intuitively aware of the true source of intelligibility, order and fullness lying behind the empirical and material existences. That is, modernity with its denial of the transcendental has taken us down a wrong path, and it is the task of the spiritually attuned philosopher to reverse out of the cul de sac by bringing the experiences of the ultimate Beyond back to the central position they once enjoyed in the ancient civilizations. 
To accomplish such a bold objective requires both a) an identification and critique of "false prophets", i.e., ideological movements that attempt to offer salvation through human and institutional action within an immanent reality of organizations and organizing, and b) a project of reawakening the lost experiences and symbols of religious experience within the confines of modern theory and practice of organization.

Voegelin (1952) was particularly concerned about the quasi-religious ideologies that promise salvation in this-worldly context through human-led reforms and revolutions. This is a warning against totalizing ideologies that is not dissimilar to the exposition of the Grand Narratives by Lyotard (1984) in his treatise on the postmodern age. But Voegelin (1952) is not directly suggesting the demise of narratives and symbols of divine teleology and the corresponding shift to the aesthetics of minor stories in a Lyotardian fashion. Instead, he is criticizing the removal of mystery from the use of religious symbols and narratives, and the associated postulation of this-worldly eschaton in the social and political ideas of the day. Modernity, with its confidence invested in human secular reason, should not confuse the immanent world with transcendent themes and perspectives. Inviting pantheistic (Cooper 2006) conceptions of spirit as the Gnostic or Hermetic (Magee 2001) knowledge of the totality is a damaging enterprise for Voegelin as it puts the human being to the apex of intellectual evolution and could thus lead to anthropocentric hubris vis-à-vis the true perfection located in the divine Beyond.

While Voegelin's critique is directed at the quasi-religious movements within the domain of politics, an application of his diagnosis within management could focus attention to the potentially problematic consequences of the organizational spirituality discourse and practice. Despite its internal contradictions, the dominant themes and perspectives within organizational spirituality (Mitroff and Denton 1999; Quatro 2004) attest to a syncretic, non-confessional approach that resonates with the New Age movement and the related Eastern religious traditions (O'Neil 2001). The focus is on the individual and his or her pursuit of spiritual enlightenment through practices of self-transcendence. The most obvious manifestations of the spirituality movement can be found in the practices of yoga and meditation (Heelas and Woodhead 2005), which originate from the religious philosophies of Hinduism and Buddhism.

The Gnostic texture is evident in the notion that practicing spirituality can lead to a clearer vision of the nature of reality through the removal of the materialist and instrumental distortions of the established institutional beliefs (Vasconcelos 2009). Spirituality discourse tends to stress the benefits of spiritual exercises to the opening up of the worldly mind in areas like decision-making and leadership (Delbecq 2010). Ultimately, the aim of the discourse of spirituality is a kind of emptying of the self from its materialistic and egoistic shackles for the pursuit of higher ethical values.

In many places, the spirituality movement is satisfied with merely articulating an alternative programme of self-development and self-transcendence to the managerial and leadership field, or accounting for the instrumental value of spirituality (Karakas 2010). However, some of the streams in the spirituality thought advocate also a transformative social and organizational agenda. The idea is that spirituality can support a progressive (Zsolnai 2004) or liberating (Bell 2007) change by way of offering a superb ethical and epistemological clearing for organizational and managerial cognition. Here spirituality not only refers to the quest for opening up human consciousness to the transcendent, but also argues for an intimate link between spiritual enlightenment and the vanguard project of societal improvement (Pruzan 2011). Spiritualized individuals are superlatively equipped with real knowledge or gnosis, and are therefore more capable of challenging the decay of the distorted materialist reality (cf. Giacalone and Jurkiewicz 2003a, b). 
The problem with this type of spiritually-based progressivism is that it shifts its metaphysical stance from transcendental contemplation to immanent activism after having cleared ground for an enlightened gnostic cognition (Roberts 2008). The strict other-worldly metaphysical commitment shared by Plato (1993) and Voegelin (1952) is compromised in the spirituality discourse in the form of an ambivalent logic that accommodates both transcendence and radical immanence. While the realm of the divine Forms is crucial for the liberating self-transcendence of the individual actor, it no longer stands in the way as the spiritually enlightened persons and groups start pursuing the projects of social, economic or ecological betterment. The salvational focus moves to the immanent reality, and to the realizable utopian goals characterized by ideals such as liberty, community, equity or ecological harmony. Spiritual emancipation paves way to the idea of the chosen one leading the human history to its end (Cf. Fukuyama 1989).

If the critique of the implicit gnostic immanentization of the transcendent valorization is the critical component of Voegelin's (1952) work, the aim to re-introduce experiences of symbols of transcendence represents, in turn, the positive element within his project (Voegelin 1967). According to Voegelin, spiritual symbols embodying religious experiences have lost their meaning in the ascent of modernity. Concepts of the sacred, together with various cosmological myths have been replaced by rationalized structures that cover the major part of human consciousness in the scientific age. Signs and narratives of the transcendent are nowadays dead metaphors without the associated spiritual content of the past. In particular, organizational bureaucracies and technical-rational paradigms have narrowed the space available for symbolic appropriations of religious experience in the public sphere (Bowles 1989).

Within the management domains, the task would be to endow organizational myths with transcendental depth wherever possible. The lively tradition of organizational symbolism with its interest on the rich tapestry of cultural symbols as devices for instilling cosmological meaning to corporate life (e.g. Morgan et al. 1983; Hatch et al. 2005; Kostera 2008, 2016) could be animated to re-awaken the spiritual experience in theory and practice. This would entail focusing on those myths and concepts that articulate the ultimate reality in its various forms, including aspects such as the creation narrative, universal wisdom, infinity and the soul. Voegelin's own work gives some examples of the types of symbols that could be re-introduced to the theoretical imagination of organizational scholarship.

These include for example the concept of immortality (Voegelin 1967) that has undergone a process of decay since the emergence of modernity. Immortality of the soul as the element in human psyche that has the capability of reaching to its transcendental source is an important part of Platonist (Louth 2007) philosophy of the human - divine contact. Immortal soul could be incorporated to organizational consciousness for instance through its treatment in connection to the "soul of the leader (cf. Benefiel 2008) in a fashion that would underline the actual experience of non-material reality understood as the deeper wisdom of Platonic Forms of Truth, Justice and Beauty. The symbol of immortal soul would need an associated religious experience to retain its lost relevance for human and social ordering, but at the same time the symbol itself is the most appropriate device around which to organize the quest for the contact with the transcendental Beyond. This could entail a comparison with the related leadership capacities such as competence, vision and intelligence, and how they differ in their experiential and metaphysical resonations when contrasted to the notion of immortal soul.

Another potent site for re-spiritualizing organizational life would be in the domain of narratives and stories. Narrative organization theory has recently moved to the direction of contextually shifting practices and processes of storytelling (Boje 2001). However, the 
background of the field in narrative semiotics and mythology (Broms et al. 1987; Fiol 1989) could offer viable routes for sparking experiences of the transcendent. As Hatch et al. (2005) have demonstrated, the stories of business leaders offered for public consumption tend to reverb with the classical myths of gods and prophets found in the ancient Greek culture, illustrating themes such as paternalism, craft and vision but also divine wisdom and transcendental truths. However, despite the bold arguments they make regarding the relevance of transcendence in today's management mythology, Hatch et al. (2005) ultimately limit their discussion of the metaphysical implications and potentials of the divine metaphor by noting that the religious dimension animated in this figure of the priest or prophet should be understood primarily as a secularized role for the leader in the immanent symbolic order. In other words, they do not approach the archetype of a spiritual leader as a gateway to the relationship between the religious motifs and the actual experience of the immaterial Beyond.

From a Platonist-Voegelinian perspective, one could argue that there is a need to complement the re-instilling of symbols of transcendence with experiential practices that would enable space for mystical encounters with the divine in organizational life. In this sense, exercises such as meditation and prayer might accompany in some form the strive towards an engagement with immortal soul, priestly life or other potential symbols of transcendence. The praxis of spirituality has a certain popular legitimacy when cut off from the religious beliefs as for example the widespread acceptance of mindfulness (Gofino 2014) has demonstrated. These practices might offer a way to approach the divine darkness of the immaterial Beyond, although they would need to be supported by a philosophical awareness of the nature of deification prompted by the positive encounter with the transcendental Forms.

However, it is important to note that these suggestions are merely early sketches of what could be done to initiate a process of re-awakening the experience of the divine Beyond in organizational theory and practice. Central for any such project is the idea that the pre-modern culture can offer valid insights into the unity of religious experience and symbolism in modern organizational paradigms, but at the same time it is pivotal to understand that the past cannot be directly imitated in these endeavors. As Voegelin (1952) has consistently argued, the focus of a new type of philosophical spirituality should be on the opening of the consciousness to the depth of spiritual experiences of the transcendent in face of the rationalized structures and selfhoods of the modern immanent age. The expansion of the structure of consciousness with the help of taking part in the Platonic Forms transforms the human intentionality in a way that enables individuals and social organizations to balance the disruptive forces of materialism and anthropocentrism with the fullness of the divine order. Spirituality could in this scenario become the key to a way of life that can bring forth harmony and spiritually rational order to the unstable world of late modern organizations.

Acknowledgements Open access funding provided by Abo Akademi University (ABO).

Open Access This article is distributed under the terms of the Creative Commons Attribution 4.0 International License (http://creativecommons.org/licenses/by/4.0/), which permits unrestricted use, distribution, and reproduction in any medium, provided you give appropriate credit to the original author(s) and the source, provide a link to the Creative Commons license, and indicate if changes were made.

Publisher's Note Springer Nature remains neutral with regard to jurisdictional claims in published maps and institutional affiliations. 


\section{References}

Arnhart, L. 2002. Political questions: Political philosophy from Plato to Rawls. Illinois: Waveland Press.

Barnard, C. I. (1938/1951). The functions of the executive (9th ed.). Cambridge: Harvard University Press.

Bauman, D.C. 2018. Plato on virtuous leadership: An ancient model for modern business. Business Ethics Quarterly: 1-24.

Bell, E. 2007. Disruptive religion: The case of the catholic worker-priests (1943-1954). Journal of Management, Spirituality \& Religion 4 (4): 432-442.

Bell, E., and S. Taylor. 2016. In The Routledge Companion to Philosophy in Organization Studies. eds. Mir, R., H. Willmott, and M. Greenwood. London: Routledge.

Benefiel, M. 2003. Mapping the terrain of spirituality in organization research. Journal of Organizational Change Management 16 (4): 367-377.

Benefiel, M. 2005. The second half of the journey: Spiritual leadership for organizational transformation. The Leadership Quarterly 16 (5): 723-747.

Benefiel, M. 2008. The soul of a leader: Finding your path to fulfillment and success. Crossroad Publishing Company.

Benefiel, M., L.W. Fry, and D. Geigle. 2014. Spirituality and religion in the workplace: History, theory, and research. Psychology of Religion and Spirituality 6 (3): 175.

Boje, D.M. 2001. Narrative methods for organizational \& communication research. London: Sage.

Bowles, M.L. 1989. Myth, meaning and work organization. Organization Studies 10 (3): 405-421.

Broms, H., Gahmberg, H., \& Kaufmann, R. (1987). Semiotics of management (Vol. 53). International specialized book service incorporated.

Burrell, G. 1997. Pandemonium. London: Sage Publications.

Burrell, G., and G. Morgan. 1979. Sociological paradigms and organizational analysis: Elements of the sociology of corporate life. London: Heinemann.

Bussanich, John. 2007. Eric Voegelin's Philosophy of Myth. The European Legacy 12 (2): 187-198.

Case, P., R. French, and P. Simpson. 2012. From theoria to theory: Leadership without contemplation. Organization 19 (3): 345-361.

Chia, R., and S. Morgan. 1996. Educating the philosopher-manager De-signing the times. Management Learning 27 (1): 37-64.

Clegg, S.R., C. Hardy, T.B. Lawrence, and W.R. Nord, eds. 2006. The Sage handbook of organization studies. London: Sage.

Cooper, J. W. (2006). Panentheism-the other god of the philosophers: From Plato to the present. Baker Academic.

Cunliffe, A.L. 2009. The philosopher leader: On relationalism, ethics and reflexivity-A critical perspective to teaching leadership. Management Learning 40 (1): 87-101.

Delbecq, A. L. (2010). The impact of meditation practices in the daily life of silicon valley leaders. In: Plante, T. G. (ed.) Contemplative practices in action: Spirituality, meditation, and health, 183-204. ABC-CLIO.

Donaldson, L. 2001. The contingency theory of organizations. Thousand Oaks, CA: Sage.

Draper, P. (2017) Atheism and agnosticism, the Stanford encyclopedia of philosophy (fall 2017 edition), Edward N. Zalta (ed.), URL = <https://plato.stanford.edu/archives/fall2017/entries/atheism-agnosticism/>.

Durkheim, E. (1912/1976). The elementary forms of the religious life. Routledge.

Federici, M.P. 2002. Eric Voegelin: The restoration of order. Wilmington, DE: ISI Books.

Ferrara, A. 2015. Varieties of transcendence and their consequences for political philosophy. The European Legacy 20 (2): 109-119.

Fiol, C.M. 1989. A semiotic analysis of corporate language: Organizational boundaries and joint venturing. Administrative Science Quarterly: 277-303.

Foucault, M. (1997) Ethics: Subjectivity and truth. The essential works 1. Rabinow, P. (ed). London: Allen lane.

Fry, L. 2003. Toward a theory of spiritual leadership. Leadership Quarterly 14: 693-727.

Fukuyama, F. (1989). The end of history? The National Interest, 16(summer 1989), 3-18.

Giacalone, R.A., and C.L. Jurkiewicz. 2003a. Right from wrong: The influence of spirituality on perceptions of unethical business activities. Journal of Business Ethics 46 (1): 85-97.

Giacalone, R.A., and C.L. Jurkiewicz, eds. 2003b. Handbook of workplace spirituality and organizational performance. New York, NY: M.E. Sharpe.

Gofino, J. 2014. Google's head of mindfulness: 'goodness is good for business'. Guardian 14 (5): 2014 http:/www.theguardian.com/sustainable-business/google-meditation-mindfulness-technology.

Gotsis, G., and Z. Kortezi. 2008. Philosophical foundations of workplace spirituality: A critical approach. Journal of Business Ethics 78 (4): 575-600.

Grint, K. 1997. Leadership: Classical, Contemporary, and Critical Approaches. Oxford: Oxford University Press. 
Hadot, P. 1995. Philosophy as a way of life: Spiritual exercises from Socrates to Foucault. Edited with an introduction by A. Davidson. Oxford: Blackwell.

Harter, N. 2006. Voegelin's ladder. Integral Review 2: 78-89.

Hatch, M.J., and A.L. Cunliffe. 2006. Organization theory. Modern, symbolic and postmodern perspectives. Oxford: Oxford University Press.

Hatch, M.J., M. Kostera, and A.K. Kozminski. 2005. The three faces of leadership: Manager, artist, priest. Blackwell.

Heelas, P., and L. Woodhead. 2005. The spiritual revolution: Why religion is giving way to spirituality. Oxford: Blackwell.

Kaufman, Herbert. 1964. Organization theory and political theory. American Political Science Review 58 (01): 5-14.

Heyl, B. (1968). The Harvard 'Pareto circle'. In S. R. Clegg (Ed.), central currents in organization studies II: Contemporary trends (Vol. 2, pp. 3-23). London: Sage. (original work published in journal of the history of Behavioural sciences (1968), 4, pp. 316-334).

Hughes, G. 1999. The politics of the soul: Eric Voegelin on religious experience. Rowman \& Littlefield.

Hughes, G. 2003. Transcendence and history : The search for Ultimacy from ancient societies to postmodernity. Columbia: University of Missouri Press.

Hume, D. 1957. The natural history of religion. Stanford University Press.

Husserl, E. (1900) [2nd, revised edition 1913], logical investigations, trans. J. N. Findlay, London: Routledge 1973.

James, W. (1902). The varieties of religious experience: A study in human nature.

Jardine, M. 1995. Eric Voegelin's interpretation (s) of modernity: A reconsideration of the spiritual and political implications of Voegelin's therapeutic analysis. The Review of politics 57 (04): 581-606.

Jones, C., and R. ten Bos, eds. 2007. Philosophy and organization. London: Routledge.

Karakas, F. 2010. Spirituality and performance in organizations: A literature review. Journal of Business Ethics 94: 89-106.

Kavanagh, D. 2004. Ocularcentrism and its others: A framework for metatheoretical analysis. Organization Studies 25 (3): 445-464.

Keller, R.T. 1984. The Harvard "Pareto circle" and the historical development of organization theory. Journal of Management 10: 193-204.

Klein, S. 1988. Plato's statesman and the nature of business leadership: An analysis from an ethical point of view. Journal of Business Ethics 7 (4): 283-294.

Klosko, G. 2006. Development of Plato's political theory. Oxford University Press.

Kostera, M., ed. 2008. Mythical inspirations for organizational realities (pp. 163-169). London: Palgrave Macmillan.

Kostera, M. (Ed.). (2016). Organizational olympians: Heroes and heroines of organizational myths. Springer.

Krishnakumar, S., and C.P. Neck. 2002. The "what", "why" and "how" of spirituality in the workplace. Journal of Managerial Psychology 17 (3): 153-164.

Louth, A. (2007). The origins of the Christian mystical tradition: From Plato to Denys. OUP Oxford.

Lukács, G. 1971. History and class consciousness: Studies in Marxist dialectics. Vol. 215. Cambridge, Mass.: MIT Press.

Lyotard, J.F. 1984. The postmodern condition: A report on knowledge. Trans. G. Bennington and B. Massumi. Minneapolis, MN: University of Minnesota Press.

Magee, G.A. 2001. Hegel and the hermetic tradition. Cornell University Press.

March, J.G., and H.A. Simon. 1958. Organizations. New York, NY: Wiley.

Mayhew, L. 1984. In defense of modernity: Talcott Parsons and the utilitarian tradition. American Journal of Sociology: 1273-1305.

Mayo, E. 1933. The human problems of an industrial civilization. New York, NY: Macmillan.

McKee, M.C., J.H. Mills, and C. Driscoll. 2008. Making sense of workplace spirituality: Towards a new methodology. Journal of Management, Spirituality \& Religion 5 (2): 190-210.

Merton, R. 1940. Bureaucratic structure and personality. Social Forces 18: 560-568.

Michels, R. 1915. Political parties: A sociological study of the oligarchical tendencies of modern democracy. New York: Hearst's International Library Company.

Mitroff, I., and E.A. Denton. 1999. A study of spirituality in the workplace, 83-92. Summer: Sloan Management Review.

Moreno-Riaño, G. 2001. The etiology of administrative evil Eric Voegelin and the unconsciousness of modernity. The American Review of Public Administration 31 (3): 296-312.

Morgan, G., P.J. Frost, and L.R. Pondy. 1983. Organizational symbolism. Organizational symbolism. 3: 35.

Murdoch, I. 1994. Metaphysics as a guide to morals. Penguin.

Nietzsche, F. 1994. On the genealogy of morality. Trans. K. Ansell-Pearson and C. Diethe. In Cambridge texts in the history ofpolitical thought. New York: Cambridge University Press. 
Nightingale, A. 2004. Spectacles of truth in classical Greek philosophy: Theoria in its cultural context. Cambridge University Press.

Nussbaum, M. 1998. Plato's republic : The good society and the deformation of desire / Martha Nussbaum. Washington : Library of Congress. Bradley Lectures Series Publication.

O’Meara, D.J.P. 2003. Platonic political philosophy in late antiquity. Oxford: Clarendon Press.

O'Meara, D.J. 2005. Platonopolis: Platonic political philosophy in late antiquity. Oxford.

O'Neil, D.N. 2001. The new age movement and its societal implications. International Journal of Social Economics 28 (5/6/7): 456-475.

Pandey, A., and R.K. Gupta. 2008. Spirituality in management a review of contemporary and traditional thoughts and agenda for research. Global Business Review 9 (1): 65-83.

Parsons, T. 1937. The structure of social action. New York, NY: McGraw-Hill.

Peltonen, T. 2016. Organization theory: Critical and philosophical engagements. Emerald.

Peltonen, T. 2017. Spirituality and religion in organizing: Beyond secular leadership. Palgrave Macmillan.

Peltonen, T., H. Gaggiotti, and P. Case, eds. 2018. Origins of organizing. London: Edward Elgar Publishing.

Plantinga, A. (2011). Where the conflict really lies: Science, religion, and naturalism. OUP USA.

Plato. 1993. Republic. Translated with an Introduction and Notes by Robin Waterford. Oxford: Oxford University Press.

Poole, E. 2008. Organisational spirituality - A literature review. Journal of business ethics. Volume: 84. Issue 4: $577-588$.

Popper, K. (1944) Open society and its enemies.

Pruzan, P. 2011. Spiritual-based leadership. In Handbook of spirituality and business, ed. L. Bouckaert and L. Zsolnai. London: Palgrave Macmillan.

Quatro, S.A. 2004. New age or age old: Classical management theory and traditional organized religion as underpinnings of the contemporary organizational spirituality movement. Human Resource Development Review 3 (3): 228-249.

Reed, M. 2006. Organisational theorising: A historically contested terrain. In The Sage handbook of organization studies, ed. S.R. Clegg, C. Hardy, T.B. Lawrence, and W.R. Nord, 19-54. London: Sage.

Remes, P. 2008. Neoplatonism. Stocksfield. UK: Acumen.

Roberts, J. 2008. The 'returns to religion': Messianism, Christianity and the revolutionary tradition. Part I: 'Wakefulness to the future'. Historical Materialism 16 (2): 59-84.

Rodrigues, H.P., and J.S. Harding. 2008. Introduction to the Study of Religion. London: Routledge.

Rothlisberger, F., and W. Dickson. 1939. Management and the worker. An account of a research program conducted by the Western electric company, Hawthorne works, Chicago. Cambridge, MA: Harvard University Press.

Sandelands, L.E. (2003) The argument for god from organization studies. Journal of management inquiry, June 2003; vol. 12, 2: Pp. 168-177.

Scott, W.R. 2013. Institutions and organizations: Ideas, interests, and identities. Sage Publications.

Selznick, P. 1949. TVA and the grass roots. Berkeley: University of California Press.

Schilderman, Hans. 2014. Religion as concept and measure. Journal of Empirical Theology 27 (1): 1-16.

Simmel, G. 1905. A contribution to the sociology of religion. The American Journal of Sociology 11 (3): 359 376.

Simon, H.A. 1947. Administrative behavior; a study of decision-making processes in administrative organization. New York: Free Press.

Sotiropoulos, G. 2015. Bodies of truth: Eric Voegelin's ontology of participation and the potentialities of embodied being. Contemporary Political Theory 14 (2): 120-136.

Starbuck, W.H. (2003) The Origins of Organization Theory, In Christian Knudsen and Haridimos Tsoukas (eds.): The Oxford Handbook of Organization Theory. Oxford. 143-82.

Strauss, L. 1959. What is political philosophy? And other studies: University of Chicago Press.

Takala, T. 1998. Plato on leadership. Journal of Business Ethics 17 (7): 785-798.

Tsoukas, H., and R.C. Chia, eds. 2011. Philosophy and organization theory. Research in the Sociology of Organization, Vol 32. Bingley: Emerald Group Publishing.

Vasconcelos, A. V. (2009) Intuition, prayer, and managerial decision-making processes: a religion-based framework, Management Decision, Vol. 47 Iss: 6, pp.930-949.

Voegelin, E. 1952. The new science of politics: An introduction. University of Chicago Press.

Voegelin, E. 1967. Immortality: Experience and symbol. Harvard Theological Review 60 (03): 235-279.

Voegelin, E. (1974). Order and history, Vol. 4, The Ecumenic Age (Baton Rouge, LA. La Philosophie du Droit.

Vries, M.F. 1991. Whatever happened to the philosopher-king? The leader's addiction to power. Journal of Management Studies 28 (4): 339-351.

Weber, M. (1920/1930/1976) the protestant ethic and the spirit of capitalism. Routledge.

Whitehead, A.N. 1926. Religion in the making: Lowell lectures 1926. Fordham Univ Press. 
Whitehead, A. N. (1929). Process and reality: An essay in cosmology.

Williamson, T. 2008. The good society and the good soul: Plato's republic on leadership. The Leadership Quarterly 19 (4): 397-408.

Zsolnai, L. 2004. Spirituality and ethics in management. Dordrecht: Springer.

Tuomo Peltonen is professor of organization and management at Åbo Akademi University, Finland. He received his PhD from Aalto University School of Business (formerly Helsinki School of Economics). Dr. Peltonen has published about 30 articles and book chapters, and five books. His current research interests include history and philosophy of organization theory, spatiality, wisdom and religion. Latest books include Organization Theory (Emerald, 2016), Spirituality and Religion in Organizing (Palgrave, 2017), Towards Wise Management (Palgrave, 2018) as well as Origins of Organizing (edited with Hugo Gaggiotti and Peter Case; Edward Elgar, 2018). $\mathrm{He}$ is an Editorial Board member of Organization Management Journal and International Journal of HRM. 